\title{
Telling Times: \\ Time and Ritual in the Realization of the Early Egyptian State
}

\author{
Alice Stevenson
}

\begin{abstract}
The increasing use of Bayesian-modeled absolute chronologies has met with calls for more sophisticated accounts of not just our perception of archaeological time, but also of past temporal experience. Using a case study of fourth-millennium BC Egypt this article seeks to address this. It is a period that has long been perceived through a detailed relative framework, a legacy of Flinders Petrie's development of seriation. Yet this legacy imparted more than a framework, for its origins within nineteenthcentury cultural evolutionism veiled an explanatory apparatus that encourages linear and gradualist narratives of Predynastic development. By setting a new series of absolute dates within a historically-informed critique of relative dating it is possible to question previous assumptions concerning tempos of change. This does not obviate relative typologies, however. Rather it encourages us to ask new questions as to what they might represent. It is argued that in evaluating new absolute measurements of time with reference to ritual activity that distinctive temporalities in the transformation of society can be discerned, ones in which world's first territorial state became a social reality for past communities.
\end{abstract}

\section{Introduction}

When the glass floor of human antiquity was finally broken in a deep gravel pit in St Acheul, France, in April 1859 (Gamble \& Kruszynski 2009), what was exposed was a controversial abyss of possible time (Murray 1993, 175). While Victorian society gave this temporal expanse a point of reference-providing it with a perceived direction and an assumed regular rate of progression-its details remained largely obscure and unintelligible. Prehistory's now cavernous depths could be given some shape by typological means building upon the work of individuals such as Thomsen, Worsaae and Montelius, but its true quantification for many was not achieved until the introduction of radiocarbon dating. For the Early British Neolithic, for example, there continued to exist, until recently, narratives constructed around a largely undifferentiated set of social practices free-floating within the fourth millennium BC (Whittle et al. 2008; Whittle et al. 2011). Only with a suite of new radiometric measurements filtered through Bayesian modeling could key sites become anchored and a greater temporal definition for the British Neolithic emerge. For the same millennium in Egypt, however, radiometric dates face a period already sharply defined through a long-standing relative chronology. Upon this scaffolding a particular account of Egyptian state formation has been enmeshed - one very often perceived to be linear, progressive and gradual.

The character of this sequence was first demonstrated by Flinders Petrie through ceramic profiling (Petrie 1899; 1901a; 1920). Despite the subjectivities inherent in his method, for Petrie it was 'another step toward [prehistoric archaeology] becoming an exact science' (Petrie 1899, 300). Over the subsequent century this desire would find further expression through the medium of spatial analysis (Kaiser 1956; 1957), mathematics (Hodson et al. 1971; Kendall 1963; 1969; Gertzen et al. 2012), chemistry (Libby 1954, 135; Hassan 1980; 1984; 1985; Hassan 
\& Robinson 1987; Savage 1998; 2001a) and computer science (Kemp 1982; Wilkinson 1996). Although these methods each sought to enhance the detail of Egyptian chronology, their primary point of reference frequently remained Petrie's typology or the periods framed within its shadow, and each tried to validate or were validated relative to these. The resulting tautologies have long been recognized (Hendrickx 1996, 36-8; 2006, 60-71; Savage 2001a). Consequently, there tends to be a rather pessimistic assessment of the value of so-called 'legacy data' for modern analysis (Köhler 2011, 5), but the challenges are not insurmountable. The remains that we have inherited from bygone excavations remain important resources for modern chronometric assessments. Equally, such studies also form a basis from which to analyze how chronologies have been constructed, the assumptions as to how time is measured, and indeed whether time is something that was ever being assessed in the first place (Dee et al. forthcoming).

Reflecting upon recent Bayesian analysis of radiocarbon dates (Dee et al. 2013) it is possible to question previous suppositions concerning the tempo of social change in fourth millennium BC Egypt and, more broadly, address how we interarticulate archaeological time with ancient social process. In so doing this paper aims both to navigate and to challenge the distinction between abstract, chronometric time on the one hand, and human, experiential time on the other (Bailey 2008; Gosden 1994; McGlade 1999, 144; Shanks \& Tilley 1987; Whittle \& Bayliss 2007, 24). Are the chronologies we build a construction of the present? Or, can they reveal something of the dynamics of past society, such as the profound developments in social complexity witnessed in fourth millennium BC Egypt from a wide area populated largely by seasonally mobile agro-pastoralists to a territorial state headed by the institution of divine kingship? By acknowledging the ritual contexts from which the data for early Egyptian chronological analysis emerge I argue here for the latter: that the archaeological phasings recognized for Predynastic and Early Dynastic Egypt constitute very particular temporalities that were materially created and experienced in ritual space. These draw attention to the staccato and arrhythmic aspects of temporal flow, both in our chronologies and in ancient Egyptian perceptions of socio-political realities as society was drawn into a new frame of time at the end of the fourth millennium BC with the establishment of Egypt's First Dynasty. Two features of the chronometric analysis recently conducted are used here as case studies to explore these ideas: the transition from Naqada IIC/D to Naqada IIIA, and the temporal disjunction between the Predynastic and the First Dynasty.

\section{Historical Background: Making time for early Egypt}

Introductory textbooks frequently cite Petrie's development of seriation as a milestone in archaeology's emergence as a scientific discipline. It is an intellectual accomplishment that is often regarded as simply a technical one in the history of archaeology (Trigger 1996, 290-7). It was, however, realized within particular nineteenth-century social evolutionary constructions of knowledge that serve as an important reminder of the need to critically approach the assumptions that underpin one of our most fundamental points of reference.

Petrie's first edition of his History of Egypt in 1894 contained only a brief chapter devoted to prehistoric Egypt, but it conspicuously lacked any material references. Yet by the turn of the century Petrie could declare that he had 'seen the whole prehistoric times of a country arranged in an exactly graded order and development' (Petrie 1901a, 36). He achieved this by creating a sequential order out 
of the accumulated mass of ceramics (Fig. 1) from more than 900 graves excavated at the cemeteries of Naqada (Petrie \& Quibell 1896) and Diospolis Parva (Petrie 1901). His methodology for organizing this data (Petrie 1899) was embedded within the typological practices and cultural evolutionary vocabulary of the time, including the serial numismatics of John Evans (1850; Schlanger 2010), the cultural evolutionism of Edward Tylor (1871) and in particular the notion of sequence that lay behind the arrangement of A.H.L.F Pitt-Rivers' vast collection (Lane Fox 1875, 308).

Pitt-Rivers' conception of cultural evolution owed more to the work of Herbert Spencer than to Darwin (Lane Fox 1875, 298) and was underpinned by ardent conservative beliefs in evolutionary gradualism (Chapman 1985). Such conservatism also characterized Petrie's worldview (Petrie 1907; 1911; Drower 1985, 342-3). The strongest echoes of such thinking appear in Petrie's concluding statement to his paper on sequences in prehistoric remains:

In all of these series of changes in slates and tools we see a regular progression... and thus this regularity of the results is the strongest proof of the true and solid basis of the classing by sequence dates.

(Petrie 1899, emphasis added)

Consequently, gradualism formed an integral part of not just Petrie's chronological framework, but also simultaneously became the very explanatory apparatus for Predynastic development (Lucas 2005, 10; Hodder 1993, 268).

The most salient example of such theories for Petrie was the 'degeneration of form' he identified in the class of pottery he had dubbed 'wavy-handled ware' (WWare). Reiterating the language of Pitt-Rivers, Evans and Spencer, Petrie hypothesized that there was a progressive deterioration in the manufacture of such forms over time, from the earliest globular vessels with pronounced wavy handles to cylindrical examples bearing only an undulating line under the rim. This observation gave his sequence a backbone around which his large-scale sorting of the remaining pottery assemblages could proceed (Fig. 2). This was achieved with a view to minimize the chronological dispersion of each pottery type (Hendrickx 2006; Kemp 1982; Kendall, 1963, 659-61; Savage 2001a, b). The resulting arrangement of some 900 graves was divided into 50 groups numbered between 30 and 80 . These would form his sequence dates (SD). His excavations at Abydos a few years later provided a historical succession of rulers of the First Dynasty (Petrie 1900; 1901b) and a sheave from which his prehistoric sequence could hang. The work of his students, Brunton and Caton-Thompson (1928), appended the Badarian earlier than his sequence, although the SD system was never extended to incorporate these discoveries.

Petrie recognized that his technique was not one that measured time. It was merely an ordinal gradation, with 'varying relation to a scale of years in different parts of the scale' (Petrie 1899, 295). Its neat structure, however, was seductive in the narrative of progressive, regular change that it presented. It was this account of the past, predicated on typology as gradual social evolution and degeneration (Petrie $1899,297)$ that was the crucial point, not the variability or the idiosyncrasies masked with in it. These include the interspersion of globular forms of W-ware far later in the sequence than presented in Petrie's iconic diagrams. The non-conformity of W-ware's mythologized sequence has been noted at several other sites (Baumgartel 1955, 42; Mortensen 1991, 16; Scharff 1926, 18). Nevertheless, 'degradation' of W-Ware has remained a resilient myth in most retellings of Petrie's method, from the synthetic 
overviews of Gordon Childe $(1952,8)$ to more recent exhibitions (Teeter 2011, fig. $7.5)$.

Similar to the deconstruction of W-Ware's sequencing, the minutiae of other elements in Petrie's typology has been keenly scrutinized (e.g. Payne 1990; Hendrickx 2006; 2011). Despite this, the broad outline that Petrie sketched for the Predynastic has persisted. This is particularly the case for the grouping of his sequence dates into three broad phases (Petrie 1920), which for him equated with discrete cultures: the Amratian, the Gerzean and the Semainean. In a gradual framework it was these 'invasions' of cultures that were necessary in order to institute dramatic change. Such a tripartite structure may additionally betray the construction of periodization as narrative (Hodder 1993; Lucas 2005, 51-3).

What is striking is the tenacity of this three-part scheme for the Predynastic (although on the 'Semainean' see Kantor 1944). This scaffolding survived the first rigorous attempt to dislodge Petrie's framework in the 1950s when Werner Kaiser (1956; 1957) sought to transcend many of the problems concerning typological sequences by way of spatial analysis of artefact types across the cemetery of Armant. Kaiser sub-divided three phases into eleven 'sub-series' referred to as stufen or 'steps' (Table 1), a term that in itself retains the spectre of gradual, even progress. This stufen system became the general point of reference for Predynastic debate for several decades before the next major reappraisal of relative dating was undertaken by Stan Hendrickx (1996; 2006). This latter scheme was predicated on a similar spatial analysis basis to Kaiser's, but focused on ceramics and was extended to include many more cemeteries. Hendrickx's resulting phasings were named after the site of Naqada and differentiated from Kaiser's scheme by the use of upper case letters (e.g. Naqada IA rather than Stufen Ia). Despite shifts in nomenclature and connotations social change in these frameworks remained, implicitly at least, evenly spaced.

\begin{tabular}{|l|l|l|l|}
\hline Kaiser & SD & Petrie & SD \\
\hline Zeitstufe Ia-c & $30-38$ & & $31-37$ \\
\cline { 1 - 1 } Zeitstufe IIa-b & $38-40 / 45$ & \multirow{2}{*}{ Amratian } & \\
\hline Zeitstufe IIc-d2 & $40 / 45-63$ & Gerzean & $38-62$ \\
\hline Zeitstufe IIIa-b & $63-80$ & Semainean & $63-76$ \\
\hline
\end{tabular}

Table 1: Comparison of Petrie's Sequence Dating and Kaiser's Stufen (based on Hendrickx 2006, 65, Table II. 1.3)

\section{Relative to absolute dates}

Relative frameworks are alluring for the rigid support they seemingly give to fragmentary data, especially for radiometric estimations. Thus notwithstanding the criticisms lobbied against the use of relative dating of pottery it remains the fundamental reference point for absolute techniques, especially when dated samples are few and far between. In such tables, charts and grids these few scattered AMS dates have been evenly stretched and compressed between pottery types or phases until the original structure is reproduced. Take, for instance, one of the first attempts to correlate radiometric dates with the relative phasing of Predynastic material. Hassan $(1985$; 1988) grouped together 95 radiometric measurements that he had 
statistically averaged and organized these into four chrono-stratigraphic phases: the Badarian and three for the Predynastic (Table 2) following Kaiser (1957). Each has a remarkably similar duration. These radiocarbon dates were later tentatively combined with Hendrickx's relative system (Hendrickx 1996, 61, 64, table 9), and have been only slightly modified in light of recent results from Abydos, cemetery U (Hendrickx 2006, table II, 1.7; Table 3). ${ }^{1}$ Other attempts to model radiocarbon dates from Predynastic contexts into phases have been generally unsuccessful (Millard \& Wilkinson 1999).

\begin{tabular}{|l|l|}
\hline Phase & Date cal. BC \\
\hline Early Predynastic (Badarian) & $4000-3900$ \\
\hline Middle Predynastic & $3900-3650$ \\
\hline Late Predynastic & $3650-3300$ \\
\hline Terminal Predynastic (Proto-Dynastic) & $3300-3050$ \\
\hline
\end{tabular}

Table 2: Predynastic absolute chronology (based on Hassan 1988, 138).

\begin{tabular}{|l|l|}
\hline Phase & Absolute Estimate cal. BC \\
\hline Naqada IA-IIB & $4000 / 3900-3600$ \\
\hline Naqada IIC-IID & $3600-3350$ \\
\hline Naqada IIIA-B & $3350-3150$ \\
\hline Naqada IIIC1-D/ First Dynasty & $3150-2920$ \\
\hline
\end{tabular}

Table 3: Concordance of radiocarbon dates with Hendrickx's relative sequence (based on Hendrickx 2006, table II 1.8).

Although explicit evolutionary explanations were increasingly abandoned over the course the twentieth century, because nineteenth-century assumptions were so entrenched within the fabric of relative time, suppositions concerning the steady tempo of change echo not only in these tables, but within overviews of social development. Hoffman's (1979) erudite processual account noted, for instance, that:

Despite the vast number of graves at Naqada and Ballas and the vast period of time spanned by the cemeteries, we are struck by the overall similarity in artifact types and their slow stylistic evolution over time.

(Hoffman 1979, 117)

Midant-Reynes $(2000,255)$ repeated these sentiments re-emphasizing how 'Petrie's discoveries quickly demonstrated that a process of gradual cultural maturation had taken place'. Similarly, in a review of Predynastic studies at the end of the twentieth century, Savage commented that a 'consensus appears to be developing that stresses the gradual development of complex society' (Savage 2001b, 101), while a recent appraisal of theories of state formation noted that it 'took place over a long period' (Köhler 2010, 37). As long as radiometric dates continued to be framed in 
periodizations that had roots in nineteenth-century evolutionary schemes, such trajectories seem not to have been rigorously questioned.

Having said that, to some extent the implicit assumption of uniform ceramic change and linearity that underlines many traditional chronologies has already been challenged by the recognition that there existed a regional patchwork of alternate trajectories of pottery production and consumption. The complex role of such regionalism was amongst the earliest critiques of Petrie's method (Naville 1914, 1-2), and more recent relative dating endeavors have sought to develop localized chronologies (e.g. Buchez 2011; Friedman 1981; Hartman 2011; Payne 1992; Stevenson 2009). In these studies existing Naqada divisions are upheld, albeit redefined in the context of each site's research questions, rather than questioning whether those temporal divisions are appropriate (cf. Ramenofsky 1998, 83). Of greater concern is that the resulting mosaic of increasingly detailed internal frameworks has not yet been effectively interleaved nor have their implications for social reconstruction been investigated. One of the outstanding barriers to achieving this is the question of whether similar types of objects or assemblages occur at different sites, at different points in absolute time (Rowland 2009; 2013, 240). There remains the possibility not just that different regional chronologies might co-vary or that there are small oscillations in the uptake of novel forms: we also have to take into consideration that there may be significant overlaps or gaps as statistical analysis of absolute data indicate (Dee et al. forthcoming). These models are based on Bayesian statistics, a technique that can enhance the precision of chronometric estimates (Bronk Ramsey 2009). Using such approaches a new timeline for early Egypt has been constructed which outlines a more mathematically-grounded temporal pattern than has been available previously. It also provides a basis to from which to challenge the gradualist paradigms that continue to dominate narratives of Egyptian state formation.

\section{Punctuating time: new models}

Relative chronologies such as Petrie's built ordinal timescales, but today's temporal research need not be directed towards this primary goal. Instead of agonizing over fitting individual absolute dates to relative phases, Bayesian modeling of accumulated radiocarbon measurements can provide a basis from which we can ask more sophisticated questions of tempo, duration and social experience. For example, Bayesian methods are increasingly demonstrating that assumptions concerning the gradual nature of social change in various parts of the world are often false, a product of generalizations based on relative typologies or the ad hoc application of radiometric dates, including sequences in South-East Asia (Higham \& Higham 2009), Britain (Whittle et al. 2008) and Polynesia (Dye 2011). Recent Bayesian modeling of radiocarbon estimates from early Egyptian contexts similarly draw into relief the uneven pace of complex social transformations.

Bayesian statistical approaches have become standard practice for radiocarbon-based chronological analysis. Initial methodological challenges (e.g. Steier \& Rom 2000; Nicholls \& Jones 2000) have long since been resolved (Bronk Ramsey 2000; Buck \& Millard 2004; Bayliss \& Bronk Ramsey 2004; Bronk Ramsey 2009) and research now focuses on more minor adjustments to the modeling process, making the outputs more robust and reliable (Lee \& Bronk Ramsey 2012; Dee \& Bronk Ramsey 2014). Despite the power of Bayesian methods, however, this does not mean simply giving absolute methods authoritative status as scientific fact or ignoring other times (cf. McGlade 1999, 142-3). Rather, it demands that we pay greater 
attention to those other times, in part because it is difficult to construct precise Bayesian models without some recourse to relative chronologies. There exists an unavoidable issue, therefore, whereby despite employing short-lived samples from well-defined contexts, Bayesian models are still dependent on relative systems. It is thus crucial to tease apart the assumptions upon which the latter are predicated and to re-situate resulting chronometric patterns within the contexts from which they emerge.

Between 2010 and 2013, a Leverhulme-funded project based at the University of Oxford, in collaboration with UCL and Cranfield University, set out to obtain and model a series of new radiocarbon estimates for the late fifth to early third millennium BC. Several specific challenges faced the project, which in turn affect the way in which the results need to be evaluated. Firstly, the current ban on exportation of fresh samples from Egypt limited the sample size for analysis. Nevertheless, the project greatly expanded the available dataset by obtaining more than 100 new measurements on organic materials procured from museum collections and a handful of freshly excavated seeds from Tell es-Sakan, an Egyptian site in the southern Levant. The samples that were selected were supported by the most secure curatorial and excavation records, and the study prioritized short-lived plant remains, such as seeds from granaries, reeds from basketry and fragments of linen (Dee et al. 2012). Several cuttings of hair and fragments of bone were also examined. The export ban also meant that findings from important new excavations in the Delta, such as at Tell el-Farkha, could not be included and the majority of data derived from the Upper Egyptian sites that had been the focus of late nineteenth- and early twentieth-century exploration. However, since these assemblages are the foundation of relative dating schemes and modern fieldwork still frequently references them it seemed pertinent to test the assumptions on which they are based. Notably, the wealth of material from the eponymous site of Naqada and the royal cemeteries of Abydos in museum collections provide strong case studies for tacking between modern chronologies and ancient temporal conditions.

A second point to note is that the radiocarbon dates for the Predynastic and Early Dynastic Bayesian models that are the focus of this paper were derived from mortuary contexts in order to maximize the validity of comparing absolute with relative dating. Although relative dating schema have been assigned to habitation remains (Ginter \& Kozlowski 1994; Midant-Reynes \& Buchez 2002), the extension of a system that was formulated on the basis of grave assemblages to habitations contexts involves an additional step away from system's base that is not easily built into the Bayesian models. As a result settlement contexts were deemed inadmissible for the study and vertical stratigraphic information - rarely found in cemeteries of the period - was not available for inclusion in the models. One exception was the habitation site of Tell es-Sakan, where five samples allocated by the current excavator, Pierre de Miroschedji, to the stratum immediately prior to the Early Dynastic period were used as a terminus post quem in the First Dynasty model. As argued more fully below, it is not presumed that the pace of change in settlements or the depositional practices of quotidian life are comparable to those of the mortuary arena. Rather the project provided the opportunity to explore one particular perspective on the timing of state formation via the proxy of ritual events associated with funerals.

The analysis utilized 84 of the new dates and 112 measurements from previously published studies, including a limited number of dates from wood samples (Dee \& Bronk Ramsey 2014). ${ }^{2}$ A series of ten Bayesian models were constructed [one 
political sequence of the First Dynasty; four separate site models for the Predynastic and Badarian periods respectively; and one model that included all available Badarian dates] using the OxCal calibration program (Bronk Ramsey 1995), allowing the project to build a new absolute timescale for this period (Table 4; Dee et al. 2013). Each of the Badarian sites was modeled as a single archaeological phase (see Wengrow et al. 2014). For the Predynastic sites, such information was predominately gained from Hendrickx's (1996) ordering of pottery phases. In these models, however, successive phases were permitted to overlap, in recognition of the fact that the associated shifts in material culture were unlikely to have been instantaneous. In spite of this additional flexibility, the Predynastic models also generated estimates for the most likely point of transition between phases. In the case of the First Dynasty, the established royal lineage was employed as a mathematical constraint to refine the radiocarbon calibrations.

For the Badarian period the existing corpus of twelve reliable dates was extended to twenty, including six fresh dates for the type-site of el-Badari (Wengrow et al. 2014). The models include estimates for the beginning of the Naqada I phase and the cession of the preceding Badarian era, coinciding in the 38th century BC, some 200-300 years later than most estimates (Hassan 1988; Köhler 2012). This challenges the tendency to begin the Naqada period at the opening of the millennium, a generalization that has become something of a self-evident truth. Such is the strength of allegiance to this chronological picture that scholars have often expressed disbelief at absolute measurements that seemed discordant with it. A recurrent example was scientific dates that placed Naqada IA much later than 4000 BC (Friedman 2011, 176; Buchez 2011, 32). Yet the new dates from the Leverhulme project bolster the case for a later commencement of Naqada IA (but see Hartmann 2011).

The four Predynastic models utilized 62 radiocarbon dates. The striking feature to emerge from this was the shortness of the interval from IIB/IIC to IID/IIIA. The study allocates considerably less time to this period than the interval from Naqada IID/IIIA to the accession of king Hor-Aha, during which the country moved from cultural to political unification. The core of the First Dynasty model (Fig. 3) consisted of a sequence of eight phases representing the eight reigns attested in written sources for this period. These phases were populated by 71 dates from two key cemeteries of the early state: Abydos (31 dates) and North Saqqara (40 dates). The Abydos results were predominantly new measurements on items from the subsidiary burials around the Royal Tombs in the Umm el-Qa'ab. Taken together, the results strongly suggest a shorter Predynastic period than is usually presented, reducing it to between 600-700 years. Overall, it is a timescale that has a very different pace of change from previous estimations.

\begin{tabular}{|l|l|}
\hline Phase & Absolute Estimate cal. BC \\
\hline Naqada IA-B & $3750(?)-3650$ \\
\hline Naqada IC-IIB & $3650-3450$ \\
\hline Naqada IIC-D & $3450-3325$ \\
\hline Naqada IIIA-IIIB & $3325-3085$ \\
\hline Naqada IIIC-D/ First Dynasty & $3085-2867$ \\
\hline
\end{tabular}


In many respects these data complement what has emerged from excavation in the last decade, including new work in Upper Egypt at Hierakonpolis and Abydos. The size and material complexity of elite burials at Hierakonpolis cemetery HK6 during Naqada I-IIB is striking. With its unique evidence for organic superstructures and elaborate interments (Friedman et al. 2011), HK6 forms a starkly different funerary arena than is attested for the rulers of the emergent Egyptian state several centuries later at Abydos (see below). This underscores the discontinuous nature of political centralization and the fits and starts that characterize early hierarchies and regimes of power. Absolute dates for the Naqada I period remain limited however and further work needs to be carried out in this area. The remainder of this paper focuses instead upon two more detailed areas of Dee et al.'s (2013) timeframe in order to explore some of the ancient social conditions that might underpin the patterns observed. First is the transition between Naqada IIC/D and Naqada III and, second, is the contrast in temporal resolution between the Predynastic and the Early Dynastic period. In both cases the scales of archaeological time and types of ancient temporal experience that we can infer may be related in more complex ways because of the primary role of ritual in constructing the archaeological record out of which chronological models have been forged.

\section{Seriated rituals: Naqada IIC-IIIA}

The archaeological study of time has tended to distinguish between two lines of enquiry: the analysis of chronological time created through dating methods-what Bailey $(2008,217)$ calls 'temporal archaeology' - on the one hand, and the investigation into the possible past experiences of time-'archaeology of time' (Bailey 2008, 217) — on the other. Similar distinctions have been made by Shanks and Tilley (1987) who differentiated between 'abstract' or 'chronological' time and 'human' or 'substantial' time (see also Gosden 1994; Ingold 1993; McGlade 1999, 144). Other multi-scaler approaches, often inspired by Braudel's Annales School, have also been applied to the archaeological record (e.g. Bintliff 1991; Knapp 1992; Harding 2005). As Bradley (1994) noted, all these sorts of time contribute to the archaeological record, although each is studied in different ways (Bailey 1983). The challenge remains how to inter-relate the varying scales, different resolutions and alternative vantage points from which the passage of time is comprehended (Robb \& Pauketat 2013, 18-19).

Ritual is one area that has been acknowledged to be particularly amenable to the archaeological scrutiny of such issues (Bradley 1994; Van Dyke 2013), because it focuses attention on the complex and recursive relationship between events and structure (Harding 2005). Ritual activities serve to alter mundane rhythms (Bloch 1977; Rappaport 1999), slow down time (Kapferer 2004) and frame the experience of temporal flow in particular ways (Douglas 1966, 64; Verhoeven 2002). Bradley (1994), using a case study of Stonehenge, argued that playing off ritual time against the archaeological evidence of sequence could be a productive way of exploring social evolution. This seems to be an equally promising line of enquiry for the early Egyptian evidence given that ceramic profiles from cemeteries have formed the primary data for Petrie and his successors' relative dating models and, moreover, that burial contexts were the source for almost all of the new samples for radiometric 
measurements. Consequently, any synthesis of temporalities must be understood within the diachronic ritual processes that provided social momentum to early Egyptian funerary display. In his approach, Bradley $(1994,217)$ envisioned chronological resolution and the character of ritual time to be merely analogous, but the perspective taken here is that the two can also be more directly inter-related. What Petrie sequenced were contiguous iterations of burial ritual. Therefore, his relative framework is based upon observations of past communities' demarcation of the passing of time within funerary traditions. Discernible transitional points between phases in relative dating systems might therefore be better conceptualized as fundamental alterations in how groups materially referenced and positioned themselves vis-à-vis previous traditions of funerary provision.

It is within this context that the transition from Naqada IIC/IID to Naqada III material culture can be reconsidered. Dee et al.'s (forthcoming) probabilistic modeling of the Naqada relative phases suggests that a significant overlap exists between the relative ceramic phases IIC-IID and IIIA1-IIIA 2 in absolute time, with this overlap centering on the contiguity of IID and IIIA1. The average date for phase IIC was evidently older than the averages for IID, IIIA1 and IIIA2. In turn, IIIA2 was obviously the youngest of the four phases. However, the probability that IID is older than IIIA1 was noted to only be 0.49 , meaning that the two phases appeared indistinguishable chronologically. Hinted at here, therefore, is a more complex picture of change, one that is non-linear and allows for simultaneity (Chirikure et al. 2012, 360).

Despite the number of dates available for both IID and IIIA1, all of the samples identified as IIIA1 were obtained from Cemetery $U$ at Abydos, a vast elite necropolis spanning almost the entirety of the fourth millennium $\mathrm{BC}$, developing into the royal burial ground of Egypt's First Dynasty towards the end of the millennium. Although more data are needed to further strengthen this observation, present evidence indicates that the phase IIIA1 occurred first at Abydos, whilst the material culture associated with Naqada IID remained prevalent elsewhere. Disparities in regional chronologies are not unexpected given what is understood about the sources and trajectories of stylistic variation (Carr \& Nietzel 1995; Conkey \& Hastorf 1990). The literature on this subject is extensive, but within it are challenges to assumptions that stylistic change is necessarily predicated upon gradual drift through time (e.g. Hodder 1990). Instead the active role of individuals and communities in appropriating and knowledgeably transforming production can be recognized (Dobres \& Robb 2000; Sewell 1992), particularly within contexts of rapid escalation in social complexity. In the case of Predynastic Egypt, ceramic production was often driven by the needs of conspicuous, display-orientated burial practices (Friedman 1994, 911). This is clear when settlement and mortuary pottery profiles are compared such as at the Upper Egyptian site of Adaima: while all of the pottery in cemeteries is attested in the settlements, the full range of forms present in the settlements is not mirrored by funerary assemblages (Buchez 1998, 86). Moreover, the percentages of forms are markedly different between contexts, with marl clay ceramics such as $\mathrm{W}$-ware ware and Decorated-ware more frequent in burials and more rarely observed in habitation deposits, and in the latter there is a statistically significant higher proportion of Rough-ware ceramics, particularly in Naqada I-IIB (Hendrickx 2006, 76). This underscores the specific choices that were made by ancient communities in how burials should be correctly furnished in the construction and enactment of tradition. In other words, mortuary time differed from everyday rhythms of material engagement by being marked by very particular forms and 'material citations' of previous 
ceremonies (Jones 2003; Pauketat 2013, 38), allowing archaeologists to trace genealogies of historical practice (Robb \& Pauketat 2013, 22).

What might this mean for Egyptian ceramic typologies? One of the signatures of Naqada IIC-D is the widespread use in burial assemblages of vessels made of marl clay, including W-ware which is the linchpin of Petrie's sequence dating. The globular forms of $\mathrm{W}$-ware (W14/19) are fairly ubiquitous across Naqada IIC-D cemetery profiles in the latter part of the fourth millennium, frequently being situated in graves above the head of the deceased, indicating their specific role in funerary ritual (Stevenson 2009). These vessels form part of the character of what has been identified as Naqada IIC-D. Naqada IIIA-B, on the other hand, is indicated to archaeologists by the use of cylindrical W-Ware forms (W49-51, 56). This need not have been the gradual 'degeneration of form' that Petrie envisaged however. What we see as a transition between 'phases' might be a socially constituted shift in the way in which tradition was materially cited in ancient burial ritual by some communities. This is possible because, as ritual theorists have long recognized, ritual is a dynamic and creative process capable of instituting subtle or sometimes even dramatic transformations in social practice (Bell 1997; contra Bradley 1994, 217). The introduction of visibly different artefacts was in effect a reorientation of funerary rites from repeatedly citing past practice to actively appropriating that practice with something new and marking life crisis events in more novel ways. What is clear is that towards the end of the fourth millennium BC those 'novel ways' were increasingly the domain of the elite, particularly those who were buried in cemetery $U$ at Abydos where the rulers of Egypt's First Dynasty were later interred (e.g. see Dreyer 2011). It here that another critical juncture in the chronometric picture emerges.

\section{Contrasting temporalities: From Predynastic to Early Dynastic Egypt}

Several discussions of social complexity and state formation have identified 'tippingpoints' (cf. Stoddart 2010; Van Dyke 2008) or 'flashpoints' (Carneiro 1998) in developmental trajectories, materialized in the rapid elaboration and increased scale of elite ideology. In the timeframe outlined by Dee et al. for early Egypt one such pivot point can be identified around 3085 BC. This represents the estimate for king Hor-Aha's accession to the throne and it delineates a transition to a different chronometric space populated by far more dates and a greater temporal resolution. Five thousand years ago Aha's reign was similarly pivotal and it can be considered to be something of a 'tipping point' in the nature of social organization and the power of the state. Comparison of Predynastic and Early Dynastic funerary arenas from which radiocarbon estimates have been derived suggests that these transformations also effected some form of collective repositioning of ancient peoples' experience of time.

For the Predynastic period the repeated citation of funerary practices across successive generations provided a point of temporal introspection for communities. This was materialized in the landscape of cemeteries, where graves rarely intersected despite centuries of use (Stevenson 2009, 182), as can be clearly seen in the map of Cemetery U (Fig. 4), but also on cemetery maps for Naqada (Petrie \& Quibell 1896, pl. LXXXVI), Naga-ed-Dêr (Lythgoe and Dunham 1965) and Gerzeh (Petrie et al. 1912, pl. XIII), for instance. In effect the past was always present as a constraining and enabling basis for social action (Mizoguchi 1993). Such physical demarcations of past lives permitted these areas to accrue a visible and tangible temporal depth (Stevenson forthcoming). This veneration of the past is also explicitly demonstrated 
by the area in front of tomb $\mathrm{U}-\mathrm{j}$, which attracted pottery offerings for several generations up to the time of king Narmer (Dreyer 2011).

Narmer's own tomb (B17/B18) on the edge of Cemetery $U$ is surprisingly modest, but his successor's, Hor-Aha's, is several orders of magnitude larger and far more complex (Fig.5). Rather than a singular burial being set directly within the wider landscape of its forebears, from Aha's reign onwards each ruler's tomb lay within its own complex of carefully choreographed subsidiary burials created to accompany the monarch to the grave. At least twenty-one individuals and seven young lions rest by Aha. King Djer's, was marked in an even more dramatic fashion by the interment of at least 318 bodies around his once richly-furnished tomb (Engel 2008). A short distance away, near the ancient settlement of Abydos, monumental enclosures for each of these rulers were erected. These too were intimately framed by the newly dead. By the end of the First Dynasty nearly 2000 people were laid to rest around the rulers and their enclosures, and if this can be accepted as human sacrifice, as circumstantial evidence seems to suggest, it is on an unprecedented scale (Morris 2013). In contrast to the ritual arena of Predynastic Cemetery U, the contemplative viewing of ancestors and the experience of temporal depth in the First Dynasty royal cemetery seems to be less important than the moment brought about by orchestrating the burial and possibly even the deaths of large numbers of individuals. As more fully argued elsewhere (Stevenson forthcoming) these First Dynasty burials constructed a very different set of social relationships and they completely re-orientated the dominant temporal frame of reference. These types of lengthy, infrequent rituals in which authority was monumentally imposed were also likely to have been profoundly altering for participants as mundane time was transcended in a dramatic and memorable fashion (Rappaport 1999, 209; Whitehouse 2004), thereby rendering new temporalities meaningful as ideological time (Gell 1992, 79). This fracture between Predynastic and Dynastic constructions of death is stark, the latter not being a simple extension of the former (Wengrow 2006, 226). Arguably, such disjunctions were necessary for the fashioning of divine kingship, an institution that was not simply an amplification of pre-existing structures, but was qualitatively different as has been recognized in other early societies, including the Zapotec and the Lowland Maya (McAnany 1995).

Petrie himself explained this break with reference to invasion and conquest (Petrie 1920, 49; 1939, 77). In the type of normative history he was writing the emergence of the early Egyptian state was narrated an outstanding historical event termed the 'unification of Egypt', for which objects such as the Narmer palette were perceived to bear witness. In the latter part of the twentieth century, neo-evolutionary frameworks dissolved the event of unification within a more diffuse solution of 'state formation' theories (summary in Köhler 2010). The notion of any event-like 'unification' leading to the establishment of the Egyptian state has been largely rejected (Köhler 2010; Midant-Reynes 2000). Instead gradual progression has taken on a new hue within the literature on social complexity in early Egypt with scholars identifying 'the state' as continuously emergent via the condition of regional protostates or chiefdoms (Yoffee 2005; Kemp 2006; Campagno 2002). Through themes like social differentiation (Bard 1994; Wilkinson 1996), centralization/urbanism (Hoffman et al. 1986; Mortensen 1991) and conflict (Bard 1987; Campagno 2004) scholars have teased apart the various possible trajectories in the drawn out and multifaceted cultural integration of northern and southern Egypts. This undoubtedly took place prior to political consolidation and, as Köhler $(2010,50)$ rightly acknowledges, these processes cannot be reduced to a single narrative or theory. Whichever model 
frames the discussion, however, 'events' are categorically excluded. Yet it is hard not to be struck by the phenomenal spectacle and the dramatic material escalation of funerary proceedings of the Early Dynastic period, beginning with the end of the reign of Hor-Aha and continuing for the whole of the First Dynasty in the burial monuments of subsequent rulers. The monumental First Dynasty tombs of Saqqara are further testament to this (Emery 1961).

Following Lucas (2008) it can be argued that these constituted unprecedented events, not in the traditional historical sense, but in the archaeological sense since they involved changes in the material organization and the material infra-structure of society that had a 'high degree of irreversibility' (Lucas 2008, 63). In other words the activities of the royal court out in the desert of the Umm el-Qa'ab or on the Saqqara plateau were of such an unprecedented scale and nature (see Morris 2007; 2013; Stevenson forthcoming), demanding immense sacrifices of labour and life, that society was irrevocably altered by them. Attempting to pinpoint under which ruler(s) political consolidation of Egypt occurred may ultimately be archaeologically futile, but ascertaining the material, communal events (DeMarrais 2011) through which state ideology was performed and made vividly apparent for some ancient communities has much clearer markers in the record, including within our chronometric scales.

Returning then to our temporal scale, in terms of pottery typologies there is no break across this transition (Hendrickx 2006), although examination of materials other than pottery may yet reveal alternative temporal schema (cf. Perlès 2013). In the absolute timeframe, however, the contrast between the Predynastic and Early Dynastic is conspicuous. For the First Dynasty, the Leverhulme study was able to produce radiocarbon date ranges of high resolution on account of the concentration of samples available from Abydos and Saqqara, including many from the retainer burials giving large samples sizes for a small number of events. It has meant that as a whole the First Dynasty exhibits an average dating precision across all eight rulers of the order of decades. This stands in contrast to the Predynastic models where there was much less data, which resulted in the date ranges being significantly broader. This greater resolution is a product of sample bias. Nevertheless, it can be argued that there is a social actuality to this disparity as the very magnitude and sheer density of the material products of First Dynasty ritual pageantry associated with these events brought forth a new tangible level of detail to social, economic and political life at the end of the fourth millennium BC. This would not then be construct of our chronological classifications because what we can glimpse here may have constituted a reality for ancient Egyptian society itself. The greater resolution we can achieve is because the archaeological record manifests the massive shift in the material demarcation of ritual events that had temporal significance for past social groups in a way that it had not before.

In Egypt, as amongst the Preclassic-Classic Maya for instance (McAnany 1995), the transition to a state society was about entering a new kind of royal, genealogically-privileged time and of participating in new regimes of activity set around the episodic rituals of divine kingship and preparations for the monarch's death. In this way ritual marked the passage of time for ancient Egyptians, as apparent from year names whereby time was divided up according to the activities of individual kings (Wengrow 2006, 128). These events, in turn, leave its markers for us to measure that time (cf. Huffman 2009). Therefore, although there were undoubtedly numerous contributing factors in the construction of the Egyptian state, within these processes we might still identify those junctures that were to prove definitional not just for our own chronologies in retrospect, but which were equally apparent in the 
lived experience of past societies. In such cases any neat analytical distinctions between 'temporal archaeology' and the 'archaeology of time' begin to collapse and blur.

\section{Conclusion}

Over the course of the last century the narrative thrust of archaeology has shifted from attempting to regale history to relating social process. Robust analysis of absolute dates is vital for the latter if we are to grasp not simply the sequence and direction of change, but also to understand its tempo and duration. For Egyptian prehistory that task has only just begun and such work will require an expanded dataset if the kinds of resolution currently being achieved elsewhere are to be realized. Nevertheless, recent efforts are beginning to reveal some of the syncopated rhythms that characterize complex social development of this period and which challenge generalizing accounts of gradual change. Of equal importance in enriching our understanding of these processes, however, will be critical theorization of the ancient activities that give rise to our archaeological data, ones that permit an interpolation of our times with theirs.

Alice Stevenson

Petrie Museum of Egyptian Archaeology

$U C L$

Malet Place

London

WCIE 6BT

$U K$

Email: alice.stevenson@ucl.ac.uk

\section{Acknowledgements}

This paper is based on the Leverhulme-funded project 'Origins of Nationhood: A New Chronology for the Formation of the Egyptian State', a collaboration between the Universities of Oxford, Cranfield and UCL. I am particularly grateful to Michael Dee for the opportunity to participate in this project, as well as for helpful comments and discussions on earlier drafts of this paper. Similarly, David Wengrow provided valuable feedback on a previous version. Thanks are also due to Alastair Whittle for suggesting further reading following a seminar at the University of Cardiff where I first presented some of the ideas contained in this paper. I would also like to express sincere thanks to the anonymous peer reviewers for helping me to bring further clarity to the arguments presented. Outstanding errors remain my own.

\section{Notes}

1. Although Hendrickx notes that it is 'impossible to link the phases of the Naqada culture distinguished to an absolute chronology' (Hendrickx 2006, 90).

2. These were utilized in the First Dynasty model. In order to test the in-built age issue three models were run both with and without long-lived samples (wood and charcoal) demonstrating that their inclusion did not alter the results (see electronic supplementary material associated with Dee et al. 2013; for further comment on the use of charcoal in modeling see Dee \& Bronk Ramsey 2014). 


\section{References}

Bailey, G., 2008. Time perspectives, palimpsests and the archaeology of time. Journal of Anthropological Archaeology 26, 198-223.

Bard, K., 1987. The geography of excavated Predynastic sites and the rise of complex society. Journal of the American Research Center in Egypt 24, 81-93.

Bard, K. 1994. From Farmers to Pharaohs. Sheffield: Sheffield Academic Press.

Baumgartel, E., 1955. The Cultures of Prehistoric Egypt. Volume 1. Revised edition. Oxford: Oxford University Press.

Bayliss, A. \& C. Bronk Ramsey, 2004. Pragmatic Bayesians: a decade of integrating radiocarbon dates into chronological models, in Tools for Constructing Chronologies: Crossing Disciplinary Boundaries, eds. C.E. Buck \& A.R. Millard. London: Springer, 25-41.

Bell, C., 1997. Ritual. Perspectives and Dimensions. Oxford: Oxford University Press.

Bintliff, J., (ed.) 1991. The Annales School and Archaeology. London: Leicester University Press.

Bradley, R., 1994. Ritual, time and history. World Archaeology 23(2), 209-19.

Bronk Ramsey, C., 1995. Radiocarbon calibration and analysis of stratigraphy: the OxCal program. Radiocarbon 37, 425-30.

Bronk Ramsey, C., 2000. Comment on 'The use of Bayesian statistics for 14C dates of chronologically ordered samples: a critical analysis'. Radiocarbon 42(2), 199-202.

Bronk Ramsey, C., 2009. Bayesian analysis of radiocarbon dates. Radiocarbon 51, 337-60.

Brunton, G. \& G. Caton-Thompson, 1928. The Badarian Civilisation. (British School of Archaeology in London and the Egypt Research Account Memoir 30.) London: British School of Archaeology in Egypt.

Buchez, N., 1998. Le mobilier céramique et les offrandes à caractère alimentaire au sein des dépôts funéraires prédynastiques: éléments de réflexion à partir de l'exemple d'Adaïma. Archéo-Nil 8, 85-103.

Buchez, N., 2011. Adaïma (Upper Egypt): The stages of state development from the point of view of a 'village community', in Egypt at its Origins 3, eds. R. Friedman \& P. Fiske. (Orientalia Lovaniensia Analecta 205.) Leuven: Peeters, 31-40.

Buck, C.E. \& A. Millard, 2004. Tools for Constructing Chronologies: Crossing Disciplinary Boundaries. London: Springer. 
Campagno, M., 2002. On the Predynastic 'proto-states' of Upper Egypt. Göttinger Miszellen 188, 49-60.

Carneiro, R.L., 1998. What happened at the flashpoint? Conjectures on chiefdom formation at the very moment of conception, in Chiefdoms and Chieftancy in the Americas, ed. E.M. Redman. Gainesville (Fl): University Press of Florida, 18-42.

Carr, C. \& J.E. Neitzel, (eds.) 1995. Style, Society and Person. New York (NY): Routledge.

Chapman, W.R., 1985. Arranging ethnology. A.H.L.F. Pitt Rivers and the typological tradition, in Objects and Others. Essays on Museums and Material Culture, ed. G.W. Stocking. Madison (WI): The University of Wisconsin Press, 15-48.

Chirikure, S., M. Manyanga \& A.M. Pollard, 2012. When science alone is not enough: radiocarbon timescales, history, ethnography and elite settlements in Southern Africa. Journal of Social Archaeology 12(3), 356-79.

Childe, V.G., 1952. New Light on the Most Ancient East. London: Routledge \& Keagan Paul.

Conkey, M. \& C. Hastorf, (eds.), 1990. The Use of Style in Archaeology. Cambridge: Cambridge University Press.

Dee, M. \& C. Bronk Ramsey 2014. High-precision Bayesian modelling of samples susceptible to inbuilt age. Radiocarbon 56 (1): 83-9.

Dee, M., D. Wengrow, A. Shortland, A. Stevenson, F. Brock, L. Flink \& C. Bronk Ramsey, 2013. An absolute chronology for early Egypt using radiocarbon dating and Bayesian statistical modelling. Proceedings of the Royal Society A 469(215) doi: 10.1098/rspa.2013.0395

Dee, M.W., J.M. Rowland, T.F.G. Higham, A.J. Shortland, F. Brock, S.A. Harris \& C. Bronk Ramsey, 2012. Synchronising radiocarbon dating and the Egyptian historical chronology by improved sample selection. Antiquity 86, 868-83.

Dee, M.W., D. Wengrow, A. Shortland, A. Stevenson, F. Brock \& C. Bronk Ramsey, forthcoming. Radiocarbon dating and the Naqada relative chronology. Journal of Archaeological Science

DeMarrais, E., 2011. Figuring the group. Cambridge Archaeological Journal 21(2), 165-86.

Dobres, M.-A. \& J. Robb, (eds.), 2000. Agency in Archaeology. London: Routledge.

Douglas, M., 1966. Purity and Danger: An Analysis of the Concepts of Pollution and Taboo. London: Routledge. 
Dreyer, G., 2011. Tomb U-j: a royal burial of Dynasty 0 at Abydos, in Before the Pyramids. The Origins of Egyptian Civilization, ed. E. Teeter. (Oriental Institute Museum Publications 33.) Chicago (IL): Oriental Institute of Chicago, 131-8.

Drower, M.S., 1985. Flinders Petrie. A Life in Archaeology. London: Victor Gollancz.

Dye, T.S., 2011. The tempo of change in the leeward Kohala field system, Hawai'I Island. Rap Nui Journal 25(2), 21-30.

Emery, B., 1961. Archaic Egypt. Harmondsworth: Penguin.

Engel, E-M., 2008. The royal tombs at Umm el-Qa'ab. Archéo-Nil 18, 30-41.

Evans, J., 1850. On the date of British coins. Numismatic Chronicle xii, 127-37.

Friedman, R., 1981. Spatial Distribution in a Predynastic Cemetery: Naqa ed Dêr 7000. Unpublished MA. dissertation, University of California.

Friedman, R., 1994. Predynastic Settlement Ceramics of Upper Egypt: A

Comparative Study of the Ceramics of Hemamieh, Nagada, and Hierakonpolis.

Berkeley (CA): U.M.I. Dissertation Services.

Friedman, R., W. Van Neer \& V. Linseele, 2011. The elite Predynastic cemetery at Hierakonpolis: 2009-10 update, in Egypt at its Origins 3, eds. R. Friedman \& P. Fiske. (Orientalia Lovaniensia Analecta 205.), Leuven: Peeters, 157-91.

Gamble, C. \& R. Kruszynski, 2009. John Evans, Joseph Prestwich and the stone that shattered the time barrier. Antiquity 83, 461-75.

Gell, A., 1992. The Anthropology of Time: Cultural Constructions of Temporal Maps and Images. Oxford: Berg.

Gertzen, T. \& M. Grötschel, 2012. Flinders Petrie, the travelling salesman problem and the beginning of mathematical modeling in archaeology. Documenta Mathematica. Extra Volume: Optimization Stories, 199-210.

Ginter, B. \& J.K Kozlowski, 1994. Predynastic Settlement near Armant. Heidelberg: Heidelberger Orientverlag.

Gosden, C., 1994. Social Being and Time. Oxford: Blackwell.

Harding, J., 2005. Rethinking the great divide: long-term structural history and the temporal of event. Norwegian Archaeological Review 38(2), 88-101.

Hartmann, R., 2011. Some remarks on the chronology of the early Naqada culture. Archéo-Nil 21, 21-32.

Hassan, F., 1980. Radiocarbon chronology of archaic Egypt. Journal of Near Eastern Studies 39, 203-7. 
Hassan, F., 1984. Radiocarbon chronology of Predynastic Naqada settlement, Upper Egypt. Current Anthropology 25, 681-3.

Hassan, F., 1985. Radiocarbon chronology of Neolithic and Predynastic sites in Upper Egypt and the Delta. The African Archaeological Review 3, 95-116.

Hassan, F., 1988. The Predynastic of Egypt. Journal of World Prehistory 2, 135-86.

Hassan, F.S. \& S.W. Robinson, 1987. High-precision radiocarbon chronometry of ancient Egypt, and comparisons with Nubia, Palestine and Mesopotamia. Antiquity $61,119-35$.

Hendrickx, S., 1996. The relative chronology of the Naqada culture. Problems and possibilities, in Aspects of Early Egypt, ed. A.J. Spencer. London: British Museum, 36-69.

Hendrickx, S., 2006. Predynastic-Early Dynastic chronology, in Ancient Egyptian Chronology, eds. E. Hornung, R. Krauss \& D.A. Warburton. (Handbook of Oriental Studies, The Near and Middle East 83.) Leiden: Brill, 53-93.

Hendrickx, S., 2011. Naqada IIIA-B, a crucial phase in the relative chronology of the Naqada culture. Archéo-Nil 21, 65-80.

Higham, C. \& T. Higham, 2009. A new chronological framework for prehistoric Southeast Asia, based on a Bayesian model from Ban Nom Wat. Antiquity 83, 12544.

Hodder, I., 1990. Style as historical quality, in The Uses of Style in Archaeology, eds. M.W. Conkey \& C.A. Hastorf. Cambridge: Cambridge University Press, 44-51.

Hodder, I., 1993. The narrative and rhetoric of material culture sequences. World Archaeology 25(2), 268-82.

Hodson, F.R., D.G., Kendall, \& P. Tautu, (eds.), 1971. Mathematics in the Archaeological and Historical Sciences. Edinburgh: Edinburgh University Press.

Hoffman, M., 1979. Egypt Before the Pharaohs. New York: Knopf.

Hoffman, M.A, H.A, Hamroush. \& R.O Allen, 1986. A model of urban development for the Hierakonpolis region from Predynastic through Old Kingdom times. Journal of the American Research Center in Egypt 23, 175-88.

Huffman, T.N., 2009. A cultural proxy for drought: ritual burning in the Iron Age of southern Africa. Journal of Archaeological Science 36(4), 991-1005.

Ingold, T., 1993.The temporality of the landscape. World Archaeology 25, 152-74. 
Jones, A., 2003. Technologies of remembrance, in Archaeologies of Remembrance: Death and Memory in Past Societies, ed. H. Williams. New York (NY): Kluwer/Plenum, 65-88.

Kaiser, W., 1956. Stand und Probleme der ägyptische Vorgeschichtsforschung. Zeitscrift für Ägyptische Sprache und Altertumskunde 81, 87-109.

Kaiser, W., 1957. Zur inneren Chronologie der Naqadakultur. Archaeologia Geographica 6, 69-77.

Kantor, H.J. 1944. The final phase of Predynastic culture: Gerzean or Semainean? Journal of Near Eastern Studies 3, 110-36.

Kapferer, B., 2004. Ritual dynamics and virtual practice. Beyond representation and meaning. Social Analysis: The International Journal of Social and Cultural Practice 48(2), 35-54.

Kemp. B., 1982. Automatic analysis of Predynastic cemeteries: a new method for an old problem. Journal of Egyptian Archaeology 68, 5-15.

Kemp, B., 2006. Ancient Egypt, Anatomy of a Civilization. 2nd Edition. London: Routledge.

Kendall, D.G., 1963. A statistical approach to Flinders Petrie's sequence dating. Bulletin of the International Statistical Institute 40, 657-80.

Kendall, D.G., 1969. Some problems and methods in statistical archaeology. World Archaeology 1, 68-76.

Köhler, C., 2010. Theories of state formation, in Egyptian Archaeology, ed. W. Wendrich. Oxford: Blackwell, 36-54.

Köhler, C., 2011. Introduction: La chronologie relative de la Basse Vallée du Nil jusqu'au $3^{\mathrm{e}}$ millénaire BC. Archéo-Nil 21, 5-11.

Knapp, A.B., 1992. Archaeology, Annales and Ethnohistory. Cambridge: Cambridge University Press.

Lane Fox, A.H., 1875. On the principles of classification adopted in the arrangement of his anthropological collection, now exhibited in the Bethnal Green Museum. Journal of Anthropological Institute 4, 293-308.

Lee, S. \& C. Bronk Ramsey, 2012. Development and application of the trapezoidal model for archaeological chronologies. Radiocarbon 54(1), 107-22.

Libby, W.F., 1954. Chicago radiocarbon dates, IV. Science 119, 135-40

Lucas, G., 2005. The Archaeology of Time. London: Routledge. 
Lucas, G., 2008. Time and archaeological event. Cambridge Archaeological Journal $18(1), 59-65$.

Lythgoe, A.M. \& D. Dunham, 1965. The Predynastic Cemetery, N7000. Naga-edDêr, Part IV. Los Angeles: University of California Press.

McAnany, P.A., 1995. Living with the Ancestors. Kinship and Kingship in Ancient Maya Society. Austin (TX): University of Texas Press.

McGlade, J., 1999. The times of history archaeology, narrative and non-linear causality, in Time and Archaeology, ed. T. Murray. London: Routledge.

Midant-Reynes, B., 2000. The Prehistory of Egypt. Oxford: Blackwell.

Midant-Reynes, B. \& N. Buchez, 2002. Adaima I: Économie et Habitat. Cairo: Fouilles de l'Institut Français d'Archéologie Orientale 45.

Millard, A.R. \& T.A.H. Wilkinson, 1999. Comment on "AMS radiocarbon dates from the Predynastic Egyptian Cemetery, N7000, at Naga-ed-Der" by S.H. Savage. Journal of Archaeological Science 26, 339-41.

Mizoguchi, K., 1993. Time in the reproduction of mortuary practices. World Archaeology 25 (2), 223-35.

Morris, E., 2007. Sacrifice for the state: First Dynasty royal funerals and the rites at Macramallah's rectangle, in Performing Death. Social Analyses of Funerary Traditions in the Ancient Near East and Mediterranean, ed. N. Laneri, (Oriental Institute Seminars 3.) Chicago (IL): The Oriental Institute, Chicago, 15-37.

Morris, E., 2013. (Un)Dying loyalty: mediations on retainer sacrifice in ancient Egypt and elsewhere, in Violence and Civilization. Studies of Social Violence in History and Prehistory, ed. R. Campbell. Oxford: Oxbow Books, 61-94.

Mortensen, B., 1991. Change in the settlement pattern and population in the beginning of the historical period. Ägypten und Levante 2, 11-37.

Murray, T., 1993. Archaeology and the threat of the past: Sir Henry Rider Haggard and the acquisition of time. World Archaeology 25(2), 175-86.

Naville, E., 1914. The Cemeteries of Abydos Part I: 1909-1910. The Mixed Cemetery and Umm el-Ga'ab. London: Egypt Exploration Society.

Nicholls, G. \& M. Jones, 2001. Radiocarbon dating with temporal order constraints. Journal of the Royal Statistical Society Series C-Applied Statistics 50, 503-21.

Pauketat, T.R., 2013. Bundles of/in/as time, in Big Histories, Human Lives. Tackling Problems of Scale in Archaeology, eds. J. Robb \& T.R. Pauketat. Santa Fe (NM): SAR Press, 35-56.

Payne, J.C., 1990. The chronology of Predynastic D-ware. Eretz-Israel 21, 77-82. 
Payne, J.C., 1992. Predynastic chronology at Naqada, in The Followers of Horus: Studies Dedicated to Michael Allen Hoffman 1944-1990, eds. R. Friedman \& B. Adams. Oxford: Oxbow Books, 185-92.

Perlès, C., 2012. Tempi of change: when soloists don't play together. Arrythmia in 'continuous change'. Journal of Archaeological Method and Theory 20(2), 281-99.

Petrie, W.M.F., 1899. Sequences in prehistoric remains. Journal of the Anthropological Institute of Great Britain and Ireland 3/4, 295-301.

Petrie, W.M.F., 1900. The Royal Tombs of the First Dynasty. (Egypt Exploration Fund Memoir 18.) London: Egypt Exploration Fund.

Petrie, W.M.F., 1901a. Diospolis Parva. (Egypt Exploration Fund Memoir 20.) London: Egypt Exploration Fund.

Petrie, W.M.F., 1901b. The Royal Tombs of the Earliest Dynasties. (Egypt Exploration Fund Memoir 21.) London: Egypt Exploration Fund.

Petrie, W.M.F., 1907. Janus in Modern Life. New York: Putnum and Sons.

Petrie, W.M.F., 1911. The Revolutions of Civilisation. London: Harper Brothers.

Petrie, W.M.F., 1920. Prehistoric Egypt. (British School of Archaeology in Egypt and the Egypt Research Account Memoir 23.) London: British School of Archaeology in Egypt.

Petrie, W.M.F., 1921. Corpus of Prehistoric Pottery and Palettes. London: British School of Archaeology in Egypt.

Petrie, W.M.F., 1939. The Making of Egypt. London: Sheldon Press.

Petrie, W.M.F. \& J. Quibell, 1896. Naqada and Ballas. London: Bernard Quaritch.

Petrie, W.M.F., G.A. Wainwright \& E. MacKay (eds.), 1912. The Labyrinth, Gerzeh and Mazghuneh. Warmister: British School of Archaeology in Egypt.

Ramenofsky, A.F., 1998. The illusion of time, in Unit Issues in Archaeology. Measuring Time, Space and Material, eds. A.F. Ramensofsky \& A. Steffen. Salt Lake City (UT): University of Utah Press.

Rappaport R.A., 1999. Ritual and Religion in the Making of Humanity. Cambridge: Cambridge University Press.

Robb, J. \& T.R. Pauketat, 2013. From moments to millennia: theorizing scale and change in human history, in Big Histories, Human Lives. Tackling Problems of Scale in Archaeology, eds. J. Robb \& T.R. Pauketat. Santa Fe (NM): SAR Press, 3-34. 
Rowland, J.M., 2009. Building bridges between radiocarbon, relative and historical chronologies: the case of early Egypt, in Chronology and Archaeology in Early Egypt (The Third Millennium BC), eds. H. Vymazalová \& M. Bartá. Prague: Czech Institute of Egyptology, 37-43.

Rowland, J.M., 2013. Problems and possibilities for achieving absolute dates from Early Dynastic contexts, in Radiocarbon and the Chronologies of Ancient Egypt, eds. A.J. Shortland \& C. Bronk Ramsey. Oxford: Oxbow, 235-49.

Savage, S., 1998. AMS radiocarbon dates from the Predynastic Egypt cemetery, N.7000, at Naga-ed-Dêr. Journal of Archaeological Science 25, 235-49.

Savage, S., 2001a. Towards an AMS radiocarbon chronology of Predynastic Egyptian ceramics. Radiocarbon 43(3), 1255-77.

Savage, S., 2001b. Some recent trends in the archaeology of Predynastic Egypt. Journal of Archaeological Research 9(2), 101-55.

Scharff, A., 1926, Das vorgeschichtliche Gräberfeld von Abusir el-Meleq. Leipzig: J. C. Hinrichs.

Schlanger, N., 2010. Series in progress: antiquities of nature, numismatics and stone implements in the emergence of prehistoric archaeology. History of Science 48(3/4), 343-69.

Sewell, W.H., 1992. A theory of structure: duality, agency and transformation. American Journal of Sociology 98(1), 1-29.

Shanks, M. \& C. Tilley, 1987. Social Theory and Archaeology. Oxford: Polity Press.

Steier, P. \& W. Rom, 2000. The use of Bayesian statistics for C-14 dates of chronologically ordered samples: A critical analysis. Radiocarbon, 42(2), 183-98.

Stevenson, A., 2009. The Predynastic Egyptian Cemetery of el-Gerzeh. (Orientalia Lovaniensia Analecta 186.) Leuven: Peeters.

Stevenson, A., forthcoming. Locating a sense of immortality in early Egyptian cemeteries, in Death Has No Dominion: The Archaeology of Mortality and Immortality, eds. C. Renfrew, M. Boyd \& I. Morley, Cambridge: Cambridge University Press.

Stoddart, S.K.F., 2010. Boundaries of the state in time and space: transitions and transformations. Social Evolution History 9(2), 28-52.

Teeter, E., (ed.) 2011. Before the Pyramids. The Origins of Egyptian Civilization. (Oriental Institute Museum Publications 33.) Chicago (IL): Oriental Institute of Chicago.

Trigger, B., 1996. A History of Archaeological Thought. Cambridge: Cambridge University Press. 
Tylor, E.B., 1871. Primitive Culture. Researches into the Development of Mythology, Philosophy, Religion, Art, and Custom. London: John Murray.

Van Dyke, R., 2008. Temporal scale and qualitative social transformation at Chaco Canyon. Cambridge Archaeological Journal 18(1), 70-8.

Van Dyke, R., 2013. Ritual, timelessness and lived experience in the Pueblo world, in Big Histories, Human Lives. Tackling Problems of Scale in Archaeology, eds. J. Robb \& T.R. Pauketat. Santa Fe (NM): SAR Press, 193-206.

Verhoeven, M., 2002. Ritual and its investigation in prehistory, in Magic Practices and Ritual in the Near Eastern Neolithic, eds. H.G.K. Gebel, B.D. Hermansen \& C.H. Jensen. Berlin: ex oriente, 5-40.

Wengrow, D., 2006. The Archaeology of Early Egypt. Social Transformations in North-East Africa, 10,000 to 2650 BC. Cambridge: Cambridge University Press.

Wengrow, D., M. Dee, S. Foster, A. Stevenson \& C. Bronk Ramsey, 2014. Cultural convergence in the Nile valley Neolithic: a prehistoric perspective on Egypt's place in Africa. Antiquity 88, 95-111.

Whitehouse, H., 2004. Modes of Religiosity: A Cognitive Theory of Religious Transmission. Walnut Creek (CA): AltaMira Press.

Whittle, A. \& A. Bayliss, 2007. The times of their lives: from chronological precision to kinds of history and change. Cambridge Archaeological Journal 17(1), 21-8.

Whittle, A., A. Bayliss, \& F. Healy, 2008. The timing and tempo of change: examples from the fourth millennium cal. BC in Southern England. Cambridge Archaeological Journal 18(1), 65-70.

Whittle, A., F. Healy, \& A. Bayliss, 2011. Gathering Time. Dating the Early Neolithic Enclosures of Southern Britain and Ireland. Oxford: Oxbow Books.

Wilkinson, T.A.H., 1996. State Formation in Egypt. Chronology and Society. (BAR International Series 651). Oxford: Tempvs Reparatvm.

Yoffee, N., 2005. Myths of the Archaic State: Evolution of the Earliest Cities, States and Civilizations. Cambridge: Cambridge University Press.

\section{Author biography}

Alice Stevenson is the Curator of the Petrie Museum of Egyptian Archaeology, UCL. Her research primarily utilizes museum collections and archives as a departure points for exploring a range of themes in prehistoric archaeology, including burial rituals, social identities and material engagement, but also as a basis for studying the history of archaeology and anthropology. She works with a broad range of archaeological material, but has a particular interest in Neolithic-Early Bronze Age Egypt and surrounding areas. She is currently leading the AHRC-funded project 'Artefacts of Excavation', a collaboration between UCL and University of Oxford. 